\title{
THE ADEQUACY OF THE LAW OF THE SEA AND INTERNATIONAL ENVIRONMENTAL LAW TO THE MARINE ARCTIC: INTEGRATED OCEAN MANAGEMENT AND SHIPPING
}

Ingvild Ulrikke Jakobsen

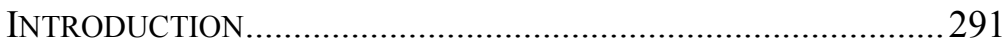

I. StARTING PoINTS - THE MARINE ARCTIC ..................2295

II. THE LEGAL FRAMEWORK FOR INTEGRATED OCEAN MANAGEMENT

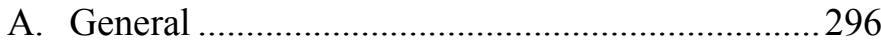

B. Integrated Ocean Management in Global Legal

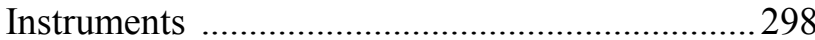

C. Regional Obligations and Cooperation Between the Arctic States

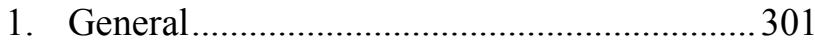

2. The OSPAR Convention................................... 303

3. The Arctic Council............................................306

III. Available AREA-Based Management TOOLS TO PROTECT THE MARINE ENVIRONMENT IN THE ARCTIC

A. General............................................................. 310

B. Area-Based Management Tools ............................ 312

1. Introduction.................................................. 312

2. Particularly Sensitive Sea Areas (PSSAs) .....316

CONCLUSION

\section{INTRODUCTION}

The marine environment in the Arctic is under pressure by climate changes and increasing human activities. ${ }^{1}$ As a result of the climate changes, the sea ice is melting, providing new

1 See Susan Joy Hassol, Impact of a Warming Arctic: Arctic Climate Impact Assessment (Cambridge University Press ed. 2004). 
opportunities for human activities. With increased human activities, such as mining and oil drilling and tourism, and the opening of new sailing routes, international shipping in the Arctic is increasing. This traffic includes cruise ships, transit, and distance shipping. ${ }^{2}$ Due to this development, the marine Arctic may come under new and increasing threats.

Shipping may have severe environmental consequences for the sensitive environment in the marine Arctic. One of the most serious threats from shipping is the risk of oil spills due to accidents. In the Arctic, oil pollution may have more severe consequences than in other areas. The infrastructure is poorly developed which will make it difficult to respond to oil spills. ${ }^{3}$ Also, it is recognized that the marine Arctic is sensitive to operational discharges from the vessels. ${ }^{4}$ Shipping may also have other environmental impacts such as physical damage to habitats and the introduction of alien species through the ballast water. The environmental consequences of Arctic shipping are reviewed in the report Arctic Marine Shipping Assessment to the Arctic Council. ${ }^{5}$ One of the recommendations provided in this report is to protect areas that are sensitive to shipping. ${ }^{6}$

The United Nations Convention on the Law of the $\mathrm{Sea}^{7}$ Articles 192 and 194 oblige states to protect and preserve the marine environment against the impacts of shipping. ${ }^{8}$ The duty reflected in Article 192, to protect and preserve the marine environment, is recognized as general international law and applies to all states in all maritime zones in the marine Arctic. The general obligations to protect and preserve the marine

${ }^{2}$ The current marine use and activity is reviewed in ARCTIC COUNCIL, ARCtic Marine ShipPing Assessment 2009 RePort (2009) [hereinafter AMSA], at 70-91, available at http://www.institutenorth.org/assets/images/ uploads/articles/AMSA_2009_Report_2nd_print.pdf.

${ }^{3}$ See generally id. at $15 \overline{4}-187$.

${ }^{4}$ See generally id. at 138-141.

${ }^{5} \mathrm{Id}$. at $134-151$.

${ }^{6} \mathrm{Id}$. at $7,152$.

${ }^{7}$ The United Nations Convention on the Law of the Sea, December 10, 1982, 1883 U.N.T.S. 397 [hereinafter "LOS"], available at http://www.un.org/depts/los/convention_agreements/texts/unclos/unclos_ e.pdf.3.

${ }^{8}$ LOS, supra note 7, arts. 192 and 194. 
environment were extended through the adoption of the 1992 Convention of Biological Diversity, ${ }^{9}$ where principles and obligations to ensure sustainable use and conservation of ecosystems and the biological diversity, were introduced. ${ }^{10}$ Under CBD, which is binding to all Arctic states except the United States, states are required to assess the biological diversity, to consider effects of shipping, to take actions to address adverse effects of shipping, and to protect areas to ensure conservation of ecosystems, habitats, and species. ${ }^{11} \mathrm{~A}$ core element of conservation of marine biodiversity is to protect sensitive areas, habitats, ecosystems, and species.

The traditional approach to the protection of the marine environment is sectoral, with distinct obligations for the states on conservation and management of living resources and protection of the environment from pollution. ${ }^{12}$ The new environmental principles and obligations, such as the precautionary principle, the conservation of biological diversity, and the ecosystem approach require, however, more holistic approaches to the management of the environment. Within the international environmental law and policy community there has been an increasing awareness of the need to adopt and implement a new integrated approach to ocean management such as those mentioned above.

With the rapid development in the Arctic region and the sensitive marine environment with unique ecosystems and rare and threatened species that are vulnerable to the impacts of climate changes, it is crucial to address the cumulative effects of the human activities through an integrated ocean management. A particular challenge with regard to regulation of shipping for the purpose of protecting the sensitive environment of the Arctic is that shipping is an international activity, governed by international regulations, and, therefore, difficult to regulate

${ }^{9}$ Convention on Biological Diversity, June 5, 1992, 1760 U.N.T.S. 29.

${ }^{10}$ Tore Henriksen, Conservation and Sustainable Use of Artic Marine Biodiversity: Challenges and Opportunities, 1 ARTIC Rev. L. \& POL. 250, 249270 (2010).

${ }^{11}$ See generally id. at 258-262.

${ }^{12} \mathrm{Id}$. at 250. 
within the maritime jurisdiction. The Arctic Coastal states are restricted by the law of the sea and the Convention on the Law of the Sea (hereinafter LOS Convention) to unilaterally regulate international shipping within their maritime zones due to the navigational rights of other states. ${ }^{13}$ The global regulatory regime and regulations and standards for maritime traffic and vessel source pollution are mainly developed through the International Maritime Organization (hereinafter IMO). ${ }^{14}$ As shipping activities represent one of the most significant threats to the Arctic marine environment, it is important to assess how the LOS Convention and the IMO regulations incorporate newer environmental principles and obligations to ensure a sustainable development and protection of the marine environment, including the marine biodiversity. With the prospects of increased shipping activities in the marine Arctic, it must be questioned whether the existing international regulations of shipping are adequate to ensure the protection of the marine environment and the marine ecosystems, species, and habitats.

The aim of this article is, first, to briefly review the legal and political process of implementation of an integrated ocean management of the marine Arctic. Thereafter, this article will examine whether there are adequate area-based management tools that facilitate the possibility of including shipping activities in this new approach to ocean management. Finally, this article will explore whether the LOS Convention and IMO conventions and regulations provide for area-based regulations that are adequate to protect sensitive marine areas in the Arctic from the impacts of shipping and to contribute to the implementation of an integrated ocean management.

${ }^{13}$ Other states enjoy, according to LOS Convention Article 17, the right of innocent passage in the territorial sea and, according to Article 58, the freedom of navigation in the exclusive economic zone. LOS, supra note 7, art. 17, 58, Dec. 10, 1982, 34 U.N.T.S. 397.

${ }^{14}$ The International Maritime Organization was established in 1948 on the basis of the 1948 IMO Convention. 


\section{Starting PoINTS - The MARINE ARCTIC}

There is no legal definition for the terms "marine Arctic" and "Arctic Ocean." When addressing questions related to the protection of the marine environment and conservation of biological diversity, there are good reasons for adopting a broad definition of the marine Arctic. Therefore, this article applies a broad definition, which includes the Arctic Ocean and its adjoining seas. ${ }^{16}$

The maritime areas of the Arctic are subject to different legal regimes. The maritime areas are ranging from the territorial sea, subjected to the sovereignty of the coastal states, to the Exclusive Economic Zones (hereinafter EEZs) where coastal states enjoy sovereign rights over natural resources and other states enjoy the right of navigation, to the high seas where the principle of the freedom of the sea applies. ${ }^{17}$ Even though most of the marine Arctic is within the maritime zones of the Arctic coastal states, there are four high seas pockets in the marine Arctic. $^{18}$

The Law of the Sea is applicable in the marine Arctic as it is in any other ocean. Also, numerous international, environmental treaties are applicable in the marine Arctic. ${ }^{19}$ However, one comprehensive, regional environmental agreement for the marine Arctic does not exist. The development and adoption of such a new comprehensive environmental regional treaty that deals with all human activities, including shipping, is also not

15 There are many different definitions applied of which areas that constitute the marine Arctic. See Rosemary Rafuse, Melting Moments: The Future of Polar Oceans Governance in a Warming World, 16:2 REV. OF EUR. Community \& InT'L EnVTl. L. 196, 197 (2007); Alf Håkon Hoel, Do We Need a Legal Regime for the Arctic Ocean?, 24 InT'L J. MARINE \& COASTAL 443, 444 (2009) (providing examples of the many different definitions applied of which areas constitute the marine Arctic).

${ }^{16}$ See Artic Council, The Arctic Ocean Review, Phase 1 AOR 2009-2011, at 4 (2011), http:/www.pame.is/amsa [hereinafter Arctic Ocean Review] (defining international measures available in the marine Artic).

${ }^{17}$ LOS, supra note 7, arts. 2, 56, 58 and 87.

18 The "Banana hole" in the Norwegian Sea, the "Loop Hole" in the Barents Sea, the "Donut Hole" in the Bering Sea and the Central Arctic.

${ }^{19}$ See Artic Ocean Review, supra note 16. 
likely to happen, as the Arctic states have expressed that the Law of the Sea is the relevant legal framework for the region. ${ }^{20}$ In this Declaration, the five Arctic Coastal states-Canada, Denmark, Norway, the Russian Federation, and the United Statesemphasized that the Law of the Sea "provides a solid foundation for responsible management" and further that "we therefore see no need to develop a new comprehensive international legal regime to govern the Arctic Ocean." 21

\section{THE LEGAL FRAMEWORK FOR INTEGRATED OCEAN MANAGEMENT}

\section{A. General}

A number of international instruments refer to the concept of integrated ocean management or an ecosystem-based management approach. ${ }^{22}$ Agenda $21,{ }^{23}$ adopted at the United Nations Conference on Environment and Development (UNCED), stated that the marine environment "forms an integrated whole" and that this requires new approaches. ${ }^{24}$ These approaches are to be "integrated in content and precautionary in ambit." 25 This was also emphasized at the 2002 World Summit on Sustainable Development (hereinafter WSSD), with the adoption of the WSSD Plan of Implementation in Johannesburg. ${ }^{26}$ Moreover, the importance of this new approach

20 Arctic Ocean Conference, Illulissat Declaration, OCEANLAw.ORG (May 27-29, 2009), http://www.oceanlaw.or g/downloads/arctic/Ilulissat_

Declaration.pdf.

${ }^{21} \mathrm{Id}$. at 1-2.

${ }^{22}$ Yoshifumi Tanaka, Zonal and Integrated Management Approaches to Ocean Governance: Reflections on a Dual Approach in International Law of the Sea, 19:4 INT'L J. MARINE \& COASTAL L. 483, 484 (2004).

${ }_{23}$ U.N. Sustainable Development, United Nations Conference on Environmental and Development: Agenda 21, SUSTAINABLEDEVELOPMENT.UN.ORG (June 3 -14, 1992) http://sustainable development.un.org/content/documen ts/Agenda21.pdf.

${ }^{24} \mathrm{Id}$. at 17.1 .

${ }^{25} \mathrm{Id}$. at 17.1 .

26 Plan of Implementation of the World Summit on Sustainable Development ๆ 30-32, Sept. 4, 2002. 
is also stressed in the report from the annual meeting of the UN Informal Consultative Process on Oceans in 2002, instituted by the United Nations General Assembly, to facilitate the review of developments in ocean affairs and the Law of the Sea, stating that, "[a]n integrated, interdisciplinary, intersectoral and ecosystem-based approach to oceans management, consistent with the legal framework provided by UNCLOS and the goals of the chapter 17 of Agenda 21 is not just desirable, it is essential., ${ }^{27}$ This new approach to the management of the oceans is also reflected in other conventions and other legal instruments that are applicable in the marine Arctic. ${ }^{28}$

There are many different formulations and definitions and many denominations applied in different instruments and documents such as: integrated oceans management, ecosystem approach, ecosystem based management, marine protected areas (hereinafter MPAs), marine spatial planning (hereinafter MSP), large marine ecosystems (hereinafter LMEs), and ocean zoning and ecosystem based management. There is not, however, any universally accepted definition of the concepts "integrated oceans management," "ecosystem approach," or "ecosystembased management" that are frequently used to describe the new holistic approaches. ${ }^{29}$ It is important to note that the concepts of MPAs and MSP are recognized as tools for the states to implement and provide for an integrated oceans management or an ecosystem based approach and, therefore, must be distinguished from the latter concepts. ${ }^{30}$

Due to the lack of any accepted definitions of the concepts "integrated ocean management" and "ecosystem- based

${ }^{27}$ GAOR, 57th Sess., ๆ 4, U.N. Doc. A/57/80 (July 7, 2002).

${ }^{28}$ PATRICIA BirNie ET AL., InTERNATIONAL LAW \& The ENVIRONMENT 384-386 (3rd 2009).

${ }^{29}$ Erik J. Molenaar, Integrated Oceans Management in the Marine Arctic: Options and Pathways to Address Identified Gaps 2 (2012) (unpublished discussion paper,„) (presented at the Shell project Cross-Sectorial Governance and Regulation in the Marine Arctic).

${ }^{30}$ Id. at 3; see Ingvild Ulrikke Jakobsen, Marine Protected areas as Tools to Ensure Environmental Protection of the Marine Artic: Legal Aspects, in ARCTIC Marine GOVERnANCE: OpPORTUnities FOR TRANSATLANTIC COOPERATION, (Elizabeth Tedsen et. al. eds., 2013). 
management /approach," both concepts will be used in this article. $^{31}$ The core ideas are similar; the cumulative impacts of various uses and pressures on the marine environment necessitate integrated approaches to its management. One may therefore describe integrated ocean management or ecosystem based management as an approach where human activities are managed in an integrated manner based on the dynamics of the ecosystems so that their structure, function, and productivity are maintained. $^{32}$

\section{B. Integrated Ocean Management in Global Legal Instruments}

The development of an integrated ocean management or an ecosystem-based approach has its normative basis both in soft law instruments- such as Agenda 21- and in global legal instruments- such as the 1982 Law of the Sea Convention, the 1992 Convention on Biological Diversity, and in fisheries law such as the 1995 Fish Stock Agreement and inter alia the Convention for the Protection of the Marine Environment (hereinafter the OSPAR Convention) at a regional level. Before reviewing the process of implementing an integrated ocean management of the marine Arctic, I will highlight some important aspects and development within international law.

As a starting point the 1982 LOS Convention has a traditional sectoral approach with a distinction between the obligations to protect the marine environment from marine pollution in Part XII and the obligations of the states to ensure management and conservation of living resources in Part V. Although the LOS Convention does not include any specific reference to an integrated ocean management or ecosystem approach, one may argue that such an approach follows implicitly and that the LOS Convention, and its provisions, is

${ }^{31}$ See also Molenaar, supra note 29, at 3.

${ }^{32}$ Ronán Long, Legal Aspects of Ecosystem-based Marine Management in Europe, 26 OCEAN Y.B. 417, 419-23 (Apr. 2012) (introducing the concept of an ecosystem-based approach). 
supportive of such a new approach. ${ }^{33}$ The general obligation of Article 192 obliges the states to "protect and preserve the marine environment." 34 According to Article 194 (5), states are required to adopt "measures necessary to protect and preserve rare or fragile ecosystems as well as the habitat of depleted, threatened[,] or endangered species and other forms of marine life." 35 This indicates that the obligation to protect the "marine environment" also include an obligation to protect marine ecosystems.

Although most of the provisions in Part XII relate to marine pollution, the broad wording of Article 192 suggests that the states are obliged to protect and preserve the marine environment from all possible activities and threats, not only from pollution. This means that states must, protect the marine environment and ecosystems against physical impacts from shipping such as coral reef damage and harsh environmental effects caused by fishing activities. ${ }^{36}$ This interpretation is supported by the inclusion of Article 193, which establishes that the natural resources shall be exploited in accordance with the duty to protect and preserve the marine environment. ${ }^{37}$ This is also confirmed by international cases like the Southern Bluefin Tuna case, stating that "the conservation of the living resources of the sea is an element in the protection and preservation of the marine environment." $" 38$ Also the Preamble, states that "the problems of ocean space are closely interrelated and need to be considered as a whole" and that the Convention aims to provide a "legal order for the oceans," indicating that Article 192 facilitates an integrated and holistic approach to the protection of the marine environment, which also include conservation of the marine ecosystems. ${ }^{39}$

${ }^{33}$ See Hanling Wang, Ecosystem Management and Its Application to Large Marine Ecosystems: Science, Law, and Politics, 35 OcEAN DEV. \& INT'L L. 41, 48-50 (2004).

${ }^{34}$ LOS, supra note 7, art. 192.

${ }^{35}$ Id. art. 194(5).

${ }^{36}$ Ingvild Ulrikke Jakobsen, supra note 30 , at 224-225.

${ }^{37}$ Id. at 224.

${ }^{38}$ International Tribunal for the Law of the Sea: Southern Bluefin Tuna Cases, 38 I.L.M. 1624, 1634, 970 (1999).

${ }^{39}$ LOS, supra note 7 , pmbl. 
The 1992 Convention on Biological Diversity (hereinafter CBD) contains obligations and principles to achieve the objectives of the Convention, which are "the conservation of biological diversity, the sustainable use of its components, and the fair and equitable sharing of the benefits arising out of the utilization of genetic resources." ${ }^{40}$ Biological diversity is defined in Article 2 of the CBD and includes marine ecosystems. ${ }^{41}$ The CBD neither expresses the ecosystem approach as a principle, nor does it explicitly require an ecosystem approach. ${ }^{42}$ Still, the principles and the obligations of the CBD reflect such an approach as an inherent and necessary element of the conservation and sustainable use of the biological diversity. Also, a number of the obligations specifically make references to ecosystems, which implies that the conservation of ecosystems is fundamental to the conservation of biological diversity. ${ }^{43}$ This is particularly the case in Article 8, which contains different measures for in situ conservation of biological diversity. ${ }^{44}$

The CBD's governing body, the Conference of the Parties (hereinafter COP), has also adopted 12 principles for the ecosystem approach, the Malawi Principles (hereinafter Principles). ${ }^{45}$ Through the adoption of the Principles, the COP elaborates on the concept of ecosystem approach and may contribute to a common understanding of the concept, making the rather vague obligations of the CBD more operational. The principles of ecosystem approach are, however, broad and difficult to apply in concrete cases.

In order to strengthen the implementation of the obligations with regard to the marine biodiversity, the COP has adopted several decisions on conservation and sustainable use of marine

${ }^{40}$ Convention on Biological Diversity art. 1, opened for signature June 5, 1992, 1760 U.N.T.S. 79 (entered into force Dec. 29, 1993).

${ }^{41}$ Id. art. 2.

${ }^{42}$ See Convention on Biological Diversity, opened for signature June 5 , 1992, 1760 U.N.T.S. 79 (entered into force Dec. 29, 1993).

${ }^{43} \mathrm{Id}$. art. 2 (the term ecosystem is included in the definition of biological diversity in Article 2 and is therefore part of the objectives in Article 1 and all the obligations of the CBD).

${ }^{44} I d$. art. 8.

${ }^{45}$ U.N. Doc. UNEP/CBD/COP/5/23 at 103-09 (May 15-26, 2000). 
and coastal biodiversity. ${ }^{46}$ Also, the COP has adopted a program of work on marine and coastal biological diversity, where the implementation of Integrated Marine and Coastal Area Management (hereinafter IMCAM) is one of five program elements. ${ }^{47}$ The objective of this program element is "to promote and improve the implementation of IMCAM at the local, national and regional level." 48 To achieve this goal of implementation, the program of work formulates operational objectives and provides suggested activities. ${ }^{49}$ As shown here, neither of these legal instruments includes a clear obligation to adopt an integrated ocean management or to take an ecosystem approach to management of the marine environment. Legal requirements for the states to adopt integrated ocean management approach and to take an ecosystem approach are, however, developing through interpretations of the obligations to protect the marine biodiversity and ecosystems included in these instruments and also through processes within the treaties.

C. Regional Obligations and Cooperation Between the Arctic States

\section{General}

The aim of this section is to review the process of the implementation of an integrated oceans management in the marine Arctic. The obligations of the states, to protect and conserve biological diversity, by the use of concepts such as integrated ocean management, are to be implemented by states at the national level. However, the marine ecosystems are large and species migrate across the maritime zones of the different states. ${ }^{50}$ Taking steps and adopting measures at the national level

46 COP Decisions, CONVENTION ON BiOlogicAl Diversity, www.cbd.int/decisions/ (last visited on Sep. 13, 2013).

${ }^{47}$ U.N. Doc. UNEP/CBD/COP/DEC/IV/5 at 32 (May 4-15, 1998); U.N. Doc. UNEP/CBD/COP/DEC/ VII/5 at 10 (Apr. 13, 2004).

\footnotetext{
${ }^{48} \mathrm{Id}$. at 11.

${ }^{49} \mathrm{Id}$. at 11-13.

${ }^{50}$ Yoshifumi Tanaka, supra note 22, at 486.
} 
are therefore challenging as it raises jurisdictional issues. This requires that the states in the Arctic cooperate to be successful in implementing an integrated oceans management of the region. ${ }^{51}$ The OSPAR Convention applies only to the marine environment in the North East Atlantic. ${ }^{52}$ The Arctic states of Norway, Denmark, Iceland, Sweden, and Finland are together with other western European countries and the European Union, Contracting Parties to the Convention. ${ }^{53}$ Russia, however, is not a contracting party, which means that not all of the European marine Arctic is covered.

With the lack of a comprehensive regional agreement in the marine Arctic, and due to the fact that not all of the Arctic states are members in relevant global conventions, political cooperation on environmental protection becomes especially important. The Arctic Council was established in $1996 .{ }^{54}$ Protection of the environment was one of its main objectives, and it serves as a forum for high-level political cooperation between the Arctic states. ${ }^{55}$ The Arctic Council does not, however, possess the competence to adopt legally binding regulations. However, in recent years the Arctic Council has begun to contribute to the development of legally binding regulations and agreements. ${ }^{56}$ Moreover, the Arctic Council may also be understood as serving a role in implementing the global

51 Tore Henriksen, supra note 10 at 268 (Henriksen emphasizes that ecosystems and threats to their functions are transboundary issues that require regional and global approaches to their management).

${ }^{52}$ Convention for the Protection of the Marine Environment of the NorthEast Atlantic art. 1, opened for signature Sept. 22, 1992, 2354 U.N.T.S. 67 (entered into force Mar. 25, 1998) [hereinafter OSPAR Convention]. www.ospar.org.

Information about the Contracting Parties is available at

${ }^{54}$ See Declaration on the Establishment of the Arctic Council, 35 ILM 1387 (1996) [hereinafter Ottawa Declaration].

${ }^{55}$ See Declaration on the Establishment of the Arctic Council, Sept. 19, 1996, 35 I.L.M. 1387 (1996).

${ }_{56}$ An example of this is the agreement on search and rescue that is negotiated under the auspices of the Arctic Council, Agreement on Cooperation on Aeronautical and Maritime Search and Rescue in the Arctic, signed in May 2011. 
obligations of the states at the regional level. ${ }^{57}$ On this basis, the efforts to implement an integrated ocean management as part of political cooperation under the Arctic Council are significant and, therefore, addressed in this section.

\section{The OSPAR Convention}

The OSPAR Convention is a comprehensive regional agreement that contains principles and obligations to ensure protection of the marine environment and marine biodiversity in the North East Atlantic. ${ }^{58}$ On the basis of Article 2 of the Convention, states are under a general obligation to take "all possible steps to prevent and eliminate pollution," and to take "necessary measures to protect the maritime area against the adverse effects of human activities," in order "to safeguard human health and to conserve marine ecosystems." 59 In 1998, Annex $\mathrm{V}$ on the protection and conservation of the ecosystems and biological diversity was adopted. It follows from Article 2 (a) in this Annex that to comply with their general obligation under the OSPAR Convention and CBD to develop strategies, plans, or programs for the conservation and sustainable use of biological diversity, the artic states must take "the necessary measures to protect and conserve the ecosystems and the biological diversity of the maritime area." ${ }^{, 0}$ The Contracting Parties are also, according to the OSPAR Convention Article 2(2) (a), required to apply the precautionary principle, which is recognised as an important element of the ecosystem based approach. ${ }^{61}$ Due to the scientific uncertainty with regard to the marine ecosystems and the environmental threats, it is logical that the precautionary principle is an important element in the

${ }^{57}$ Henriksen, supra note 10 , at 268.

${ }^{58}$.See OSPAR Convention, supra note 52.

${ }^{59} I d$. art. 2(1)(a).

${ }^{60} \mathrm{Id}$. annex $\mathrm{V}$, art 2 (a).

${ }^{61}$ Timo Koivurova \& ERiK J. MolenaAr, International Governance and Regulation of the Marine Arctic, Overview and Gap ANAlysis: A REPORT PREPARED FOR THE WWF International ARCTIC Programme 16 (2009). 
ecosystem approach or integrated oceans management. ${ }^{62}$ Although the wording of the obligation is very broad, it is reasonable that the obligation is interpreted so that the states are required to adopt measures that support an integrated oceans management, where the cumulative effects of human activities are addressed and that take account of the ecosystems structure and functions. This would also contribute to the implementation of the obligations under the CBD.

The OSPAR Commission plays an important role in developing and elaborating the substantive duties of the Contracting Parties. ${ }^{63}$ It follows from Annex V, Article 3 (1)(a) that the OSPAR Commission is under a duty to "draw up programmes and measures for the control of human activities." When doing so the Commission shall, according to Article 3 (1)(b)(IV), "aim for the application of an integrated ecosystem approach." 65

Although the OSPAR Convention takes a broad and holistic approach to the management and regulation of human activities, there are, however, explicit exceptions for fisheries management and shipping. ${ }^{66}$ This means that the Commission cannot adopt recommendations and decisions where these activities are restricted. However, when action is considered necessary, the Commission is, according to Annex V, Article 4, required to cooperate with the international and regional body or authority dealing specifically with the specific issue. ${ }^{67}$ Such cooperation is significant for the coordination of the different human activities, which is necessary for an integrated ocean management. The OSPAR Commission has established a co-operation with organizations such as the North East Atlantic Fisheries Commission (hereinafter NEAFC), the International Maritime

\footnotetext{
${ }^{62}$ Yoshifumi Tanaka, supra note 22, at 503-504.

${ }^{63}$ See OSPAR Convention, supra note 52, art. 13.

${ }^{64} \mathrm{Id}$. annex $\mathrm{V}$ art. 3(1)(a).

${ }^{65} I d$. annex V art. 3(1)(b)(IV).

${ }^{66} I d$. pmbl, annex $\mathrm{V}$ art. 4.

${ }^{67} \mathrm{Id}$. annex $\mathrm{V}$ art. 4.
} 
Organization (hereinafter IMO) and International Council for the Exploration of the Sea (hereinafter ICES) ${ }^{68}$

The OSPAR Convention does not explicitly set out an obligation of integrated oceans management or a principle of ecosystem approach. One may argue that it, due to the obligation in Annex V, Article 2, follows implicitly and is reflected through the legal duty to take all necessary measures to conserve the marine ecosystems. The ecosystem approach is adopted by the OSPAR Commission in several documents. The OSPAR Commission and the Helsinki Commission agreed to apply and to develop further the ecosystem approach by 2010 at Joint Ministerial Meeting of the Helsinki and OSPAR Commissions. ${ }^{69}$ Moreover the strategy on the Protection and Conservation of the Ecosystems and Biodiversity was adopted by the Contracting Parties in 2010 to guide the work of the Commission in the implementation of the OSPAR Convention. ${ }^{70}$ The Ecosystems and Biodiversity Strategy is adopted as one of six thematic strategies that are part of the North East Atlantic Environment Strategy and sets out- as a strategic objective- to halt the loss of biodiversity within the OSPAR Maritime Area. The North East Atlantic Strategy emphasizes the objective of the implementation of an ecosystem-based approach and notes the role of the Commission to harmonize policies and strategies, including the drawing up of programs and measures, for the protection of the marine environment. ${ }^{7}$

${ }^{68}$ Long, supra note 32 , at 438.

${ }^{69}$ Statement on the Ecosystem Approach to the Management of Human Activities, First Joint Ministerial Meeting of the Helsinki and OSPAR Commissions, Bremen, 25-26 (June 2003).

70 The North-East Atlantic. Environment Strategy: Strategy of the OSPAR Commission for the Protection of the Marine Environment of the North-East Atlantic 2010-2020, OSPAR Commission, available at http://www.ospar.org/html_documents/ospar/html/10-03e_nea_environment_ strategy.pdf.

${ }^{1}$ Id. See also Long, supra note 32, at 437-438. 


\section{The Arctic Council}

Although the Arctic Council does not have the capacity to adopt any legally binding obligations to implement an integrated oceans management in the marine Arctic, it has made some important efforts and developments in respect to adopting an integrated oceans management. ${ }^{72}$ First, the two working groups, Conservation of Arctic Flora and Fauna (hereinafter CAFF) and Protection of the Arctic Marine Environment, established under Arctic Council, have provided the states with critical knowledge about the biological diversity in the Arctic and its current and future threats. The main tasks of these working groups are to collect data about the status of the environment, including its biological diversity, and to identify, monitor, and assess the risks of human activities, as means to provide advice to the Arctic states regarding their decision-making. ${ }^{73}$

The Arctic Marine Strategy Plan (hereinafter Strategy) was adopted by the Arctic Council Ministerial Meeting in 2004. ${ }^{74}$ Two of the expressed goals in the strategic plan are to reduce and prevent pollution in the Arctic marine environment and to conserve Arctic marine biodiversity and ecosystem functions. ${ }^{75}$ In the Strategy, it acknowledges that achieving the goal of conservation of the Arctic marine biodiversity and ecosystem functions requires an ecosystem approach. ${ }^{76}$ The Strategy emphasis that it is based on new environmental principles and obligations and also embraces the ecosystem approach as the basic principle of the Strategy. ${ }^{77}$ The principle of ecosystem

72 See Molenaar, supra note 29, at 6-8; Alf Håkon Hoel, Integrated Oceans Management in the Arctic: Norway and Beyond, 2 ARCTIC REV. L. \& PoL. 186-207(2012).

${ }^{73}$ For more about the work carried out under the working groups see Timo Koivurova \& David VanderZwaag, The Arctic Council at 10 Years: Retrospect and Prospects, 40.1 Colum. L. REV. 121-194, 137-153 (2007).

74 Arctic Council: Arctic Marine Strategic Plan(Nov. 24, 2004), http://www.pame.is/images/stories/AMSP_files/AMSP-Nov-2004.pdf.

${ }^{75} I d . \S 3.0$.

${ }^{76}$ Id. $\$ 5.2$.

${ }^{77}$ Id. § 6.1. See Henriksen, supra note 9, at 272-273 (about the Strategy and its basic principle on ecosystem approach). 
approach is described in the Strategy as a modern ocean management concept that requires the coordination of human activities to reduce their impact on the environment. ${ }^{78}$ This requires improvement of knowledge about the relevant ecosystems. ${ }^{79}$ The Strategy also includes a possible methodology for the application of the ecosystem approach. ${ }^{80}$

The Best Practices in Ecosystems Based Oceans Management Project ${ }^{81}$ was initiated by the Arctic Council and was developed as a series of case studies from seven of the eight member states from 2007 to $2009 .^{82}$ The objective of the project was to present the practice and application of the Arctic states of the ecosystem based approach to ocean management. ${ }^{83}$ One finding was that all the Arctic states had adopted ecosystembased management as goal for the oceans management. ${ }^{84}$ There where, however, variations between the states with regard to the implementation of the ecosystem-based management.

Furthermore, the expert group on ecosystem-based management was appointed in 2011. The mandate of the expert group was "to consider developing a common understanding of ecosystem based management, to consider ecosystem based management principles for marine and terrestrial areas, and considering develop Arctic-specific guidelines for applying the ecosystem approach to all relevant areas of work in the Arctic Council.." ${ }^{, 86}$ The outcome of the expert group, the report on the

${ }^{78}$ Henriksen, supra note 10, at 273.

${ }^{79} \mathrm{Id}$.

${ }^{80} \mathrm{Id}$.

${ }^{81}$ Best Practices in Ecosystem-Based Oceans Management in the Arctic, Norwegian Polar Inst. RePort SERIES No. 129 (Alf H. Hoel ed., April 2009), http://brage.bibsys.no/npolar/handle/URN:NBB:no-bibsys_brage_9053?

Locale $=$ no\#.

${ }^{82}$ See Alf Håkon Hoel, Integrated Oceans Management in the Arctic: Norway and Beyond, 2 ArCTIC REV. ON L. \& PoL. (2010).

${ }^{83} \mathrm{Id}$. at 201.

${ }^{84} \mathrm{Id}$.

${ }^{85}$ For an overview of the conclusions of the case studies see Id. at 201203.

${ }^{86}$ Senior Arctic Officials Report to Ministers, ARTIC CouncIL , 7 (May 2011), http://www.arctic-council.org/index.php/en/documentarchive/category/20-main-documents-from-nuuk. 
Ecosystem-based management, was presented at the 2013 Ministerial Meeting. ${ }^{87}$ In the report, the expert group provides a definition of the concept as well as principles or ecosystembased management in the Arctic. ${ }^{88}$ This definition, principles and recommendations where approved at the ministerial meeting. ${ }^{89}$

Also, other initiatives were made under the Arctic Council to ensure protection of certain sensitive areas, which is an important element for achieving an integrated oceans management in the Arctic region. ${ }^{90}$ First, the adoption of MPAs has been high on the agenda since the establishment of Arctic Council. The Arctic Council has also endorsed the global objective of establishing a network of MPAs by $2012 . .^{91}$ This objective is however, not yet accomplished.

The prospects for shipping in the Arctic and possible environmental impacts of the shipping is examined under Arctic Council and presented in the Arctic Marine Shipping Assessment (hereinafter AMSA). ${ }^{92}$ Several recommendations to promote safety and environmental protection were provided in the AMSA report. ${ }^{93}$ Among these were that the Arctic states should identify areas of ecological significance and also to explore the need for internationally designated areas for the purpose of environmental protection. $^{94}$

As a follow up, a report was completed in December 2012 where 99 areas of heightened ecological significance were

${ }^{87}$ Ecosystem-based Management in the Arctic. The report is available at http://www.arctic-council.org/index.php/en/document-archive/category/449ebm.

${ }^{88}$ Id. annex 1 , at 9-28.

89 Arctic Council, Kiruna Declaration, 15 May 2013. Available at http://www.arctic-council.org/index.php/en/document-archive/category/425main-documents-from-kiruna-ministerial-meeting.

${ }^{90}$ See U.N. Sustainable Development, note 22, at paras. 17.7, 17.30(V), 17.85. (Emphasizing the protection of sensitive areas and fragile ecosystems).

${ }_{91}$ Arctic Marine Strategic Plan, ARCTIC Council 1, 2 (November 24, 2004), http://www.pame.is/images/ stories/AMSP_files/AMSP-Nov-2004.pdf.

${ }_{92}$ AMSA, supra note 2.

${ }^{93} \mathrm{Id}$. at $134-153$.

${ }^{94} \mathrm{Id}$. at $7,152$. 
identified. ${ }^{95}$ The Protection of the Arctic Marine Environment Working Group (hereinafter PAME), on the basis of an AMSA recommendation, initiated a project that will explore the need for and make recommendations regarding internationally designated areas to protect the Arctic Ocean from the impacts of shipping, such as MARPOL Special Areas and Particularly Sensitive Sea Areas (hereinafter PSSAs).$^{96}$ In this project, the Arctic Council will consider and develop proposals to IMO for the use of appropriate measures to protect the sensitive areas on the high seas. ${ }^{97}$ This project is co-led by Norway, the United States, Finland and Russia. ${ }^{98}$ As a follow up of this AMSA recommendation a draft report that explores the need for environmental protection and provides recommendations of available IMO measures was presented at the PAME meeting in September 2013. ${ }^{99}$

95 ARCTIC COUNCIL, IDENTIFICATION OF ARCTIC MARINE AREAS OF HEIGHTENED ECOLOGICAL AND CULTURAL SIGNIFICANCE: ARCTIC MARINE SHIPPING ASSESSMENT (AMSA) II C (2013), available at http://www.amap.no/ documents/doc/Identification-of-Arctic-marine-areas-of-heightened-ecologicaland-cultural-significance-Arctic-Marine-Shipping-Assessment-AMSA-IIc/869.

96 Status on Implementation of the AMSA 2009 Report Recommendations, Arctic Council (May 2013) AMSA, at II (D) at p. 12, available at $\mathrm{ttp} / / / \mathrm{www}$. innovation.ca/sites/default/files/Rome2013/

files/Arctic\%20Marine\%20Shipping\%20Assessment,\%20Arctic\%20Council,\% 202013.pdf.

${ }^{97} I d$.

98 Arctic Council, PAME Working Group MeEting Report NO: 12012, 7-9 (2012), available at http://www.pame.is/images/PAME_NEW/

WG_Meetings/PAME\%20I-2012\%20meeting\%20report1.pdf.

99 Det Norske Veritas, Draft 2 Report: Specially Designated ARCTIC MARINE AREAS (2013), available at http://www.pame.is/images/ PAME_II_2013_Russia/Agenda_item_4.5a_AMSA_IID_Report_Draft_2_DN V_2013-08-15.pdf. 
III. Available Area-Based Management ToOls TO PROTECT THE MARINE ENVIRONMENT IN THE ARCTIC

\section{A. General}

The flag state has jurisdiction over vessels that are flying their flag, and it has a legal duty to adopt and enforce regulations over these vessels according to Articles 94 and 211 (2) ${ }^{100}$ Due to their respective interests, the coastal states are allocated some jurisdictional rights to regulate and enforce foreign vessels that are operating in their maritime zones.

The coastal state enjoys sovereignty within the territorial sea according to the LOS Convention Article 2. ${ }^{101}$ The sovereignty is, however, limited by the right of other states to engage in innocent passage. ${ }^{102}$ The LOS Convention provides the coastal state with a right to regulate the innocent passage for the purposes of i.e. the safety of navigation, the conservation of living resources and the preservation of the environment as provided in Articles 21 and 22. ${ }^{103}$ These regulations must not hamper the innocent passage or have the practical effect of "denying or impairing the right of innocent passage," according to Article $24 .{ }^{104}$ In the EEZ, other states enjoy the right of the freedom of navigation, and the competence of the coastal states to regulate shipping is more limited. The coastal state has, however, according to Article 211 (5), the jurisdiction to adopt regulations to prevent, reduce, and control pollution from vessels. ${ }^{105}$ These regulations must, however, be "conforming to or giving effect to generally accepted international rules or standards established through the competent international organization or general diplomatic conference." 106 The IMO is in this regard recognized as the competent international

\footnotetext{
${ }^{100}$ LOS, supra note 7, arts. 94, 211 (2).

${ }^{101}$ Id. art. 2.

${ }^{102} I d$. art. 17. (Note that article 19 defines when the passage is innocent).

${ }^{103}$ Id. arts. $21 \& 22$.

${ }^{104} I d$. art. 24.

${ }^{105}$ Id. art.211 (5)

${ }^{106} \mathrm{Id}$.
} 
organization. Consequently, the competence of the Coastal states to address the environmental impacts of shipping in the EEZ is therefore limited to regulations to prevent, reduce, and control pollution, which are adopted by IMO and are "generally accepted." 107

The IMO has developed and adopted numerous regulations to achieve its objective of maritime safety and environmental protection. $^{108}$ The COLREG, SOLAS, and MARPOL Conventions provide traditional IMO regulations on shipping, such as ships reporting system and routing systems and standards for operational pollution and requirements to the construction, design, equipment and management of vessels. ${ }^{109}$ However, there have not been many regulations developed that relate specifically to shipping in the Arctic. ${ }^{110}$ To avoid accidents leading to oil spills or operational pollution in sensitive areas, routing measures such as sea-lanes could be adopted to lead the traffic outside sensitive marine areas. Even though there are regulations of general applicability that are available, and IMO has approved

107 For a discussion of what constitutes GAIRS, see Committee on Coastal State Jurisdiction Relating to Marine Pollution, InTERNATIONAL LAW AsSOCIATION 37-38 (2000), http://webcache.googleusercontent.com/search?q= cache:siFVymThZeIJ:www.ila-

hq.org/en/committees/index.cfm/cid/12+\&cd=1\&hl=en \&ct=clnk\&gl=us.

${ }^{108}$ The purpose and mandate of IMO is set out in the 1948 Convention on the International Maritime Organization. Convention on the International Maritime Organization, Art. 1, opened for signatures Mar. 6 1948, 289 U.N.T.S. 3 (entered into force Mar. 17, 1958).

${ }^{109}$ Convention on the International Regulations for Preventing Collisions at Sea, Oct. 20, 1972, 1050 U.N.T.S. 16, 18 [hereinafter COLREG]; International Convention for the Safety of Life at Sea, Nov. 1, 1974, 1184 U.N.T.S. 278 [hereinafter SOLAS]; International Convention for the Prevention of Pollution from Ships, 1973, 1340 U.N.T.S. 184 [hereinafter MARPOL].

110 See Heike Deggim, International Maritime Organization, International Requirements for Ships Operating in Polar Waters 3 (2009), available at $\mathrm{http} / / / \mathrm{www} . i m o . o r g / K n o w l e d g e C e n t r e / P a p e r s A n d$ Articles ByIMOStaff/Documents/International $\% 20$ requirements $\% 20$ for $\% 20$ ships $\% 20$ o perating\%20in\%20polar\%20waters\%20-\%20H.\%20Deggim.pdf (Deggim notes in $\S 10$ at 4 , that the only requirements in the SOLAS Convention directly relating to polar areas are contained in SOLAS chapter V) Regulation 5 in SOLAS chapter $\mathrm{V}$ requests the states "to encourage the collection of meteorological data" and to provide for weather information. $I d$. 10 , at 4. 
such measures for such environmental purposes, there are at present very few such measures adopted in the marine Arctic. ${ }^{111}$

In the AMSA report it was concluded that it is necessary to strengthen the international legal regime of shipping. ${ }^{112}$ As a response, the Guidelines for shipping in Polar waters were adopted by IMO in 2009. ${ }^{113}$ They include standards for construction and operational standards, but are not legally binding. ${ }^{114}$ There is at the present an ongoing process of developing these guidelines into a code, which could be made legally binding. ${ }^{115}$ It is, however, unclear to what extend the states will agree on environmental protection regulations that may facilitate protection of marine ecosystems and an integrated oceans management of the marine Arctic.

\section{B. Area-Based Management Tools}

\section{Introduction}

In order to conserve ecosystems and marine biodiversity, we have seen that holistic and integrated approaches are necessary. This requires the use of area- based management tools. Such tools are of significance as they provide for the possibility to address the impacts of all different human activities within a certain area. The question is then to what extent do the LOS Convention and IMO provide for such area-based management tools that are adequate to facilitate an integrated ocean management, where shipping activities are also addressed?

Even though there are limitations of the competence of the Coastal state to regulate shipping activities in their maritime

${ }^{111}$ See generally Aldo Chircop, The Growth of International Shipping in the Arctic: Is a Regulatory Review Timely?, 24 INT'L J. MARINE \& COASTAL L. 355 (2009).

${ }^{112}$ AMSA, supra note 2 at 67.

${ }^{113}$ I.M.O. Res. A.1024(26), U.N. Doc. A 26/Res.1024 (Jan. 18, 2010).

${ }^{114}$ Id. pmbl.

115 International Maritime Organization, Shipping in Polar Waters: Development of an International Code of Safety for Ships Operating in Polar Waters (Polar Code), IMO, http://www.imo.org/MediaCentre/ HotTopics/ polar/Pages/default.aspx (last visited Sept. 5,2013). 
zones, the LOS Convention provides for two types of area-based management tools, where it is possible to adopt stricter regulations to protect certain areas against the impacts of shipping. These are "special areas" as described in Article 211 (6) and ice-covered areas in Article 234. ${ }^{116}$

The coastal state may, according to Article 211 (6), subject to specific conditions related to technical reasons, oceanographic and ecological reasons in addition to the use of the area and character of the traffic, with the approval of IMO, adopt special mandatory measures for the prevention of pollution. ${ }^{117}$ It is recognized that the regulations that may be adopted may go further and be stricter than regulations that are "generally accepted" and may be adopted on the basis of Article 211 (5). ${ }^{118}$ In practice, Article 211(6) has so far not been applied. ${ }^{119}$ One explanation and reason for this could be its complicated structure, strict conditions and procedures in addition to the need of approval by IMO before adopting the mandatory measures. ${ }^{120}$ The provision, therefore, seems more of a theoretical possibility for environmental protection of certain areas rather than a practical tool for the coastal states. ${ }^{121}$

Article 234 - "the Arctic exception" - provides the coastal states of ice-covered sea areas with enhanced jurisdiction to regulate and enforce regulations of shipping. ${ }^{122}$ According to

116 Tanaka categorizes these as "MPA-related concepts", see Yoshifumi Tanaka, THE INTERNATIONAL LAW OF THE SEA, Cambridge 2012, at 325.

117 EriK J. MolenaAR, Costal State Jurisdiction OVer VesselSource Pollution 404 (David Freestone \& Daniel Bodansky eds., 1998). See $i d$. at 402-419 (discussing Article 211(6)).

${ }^{118} I d$. at 405 .

${ }^{119} \mathrm{Id}$. at 407.

${ }^{120}$ Ingvild U Jakobsen, "Marine verneområder i Arktis: Kyststatens forpliktelser og rettigheter" in Juss in Nord: Hav, fisk og urfolk, En hyllest til det juridiske fakultet ved Universitetet $i$ Tromsøs 25- årsjubileum, Tore Henriksen and Øyvind Ravna (eds.) Oslo 2012, p. 93-135, p. 115. ("Marine Protected Areas in the Arctic: the obligations and rights of the coastal state" in Law in the North: Sea, Fish and Indigenous People. A Contribution to the Faculty of Law of the University of Tromsø, Tore Henriksen and Oyvind Ravna (eds) 2012) (My translation).

${ }^{121} \mathrm{Id}$.

${ }^{122}$ See Kristin Bartenstein, The Arctic Exception in the Law of the Sea 
Article 234, the Coastal state may adopt and enforce "nondiscriminatory laws and regulations for the prevention, reduction and control of marine pollution from vessels in ice-covered areas." 123 The provision is applied by Russia and Canada, who have adopted far-reaching regulations that are stricter than the regulations that may be adopted on the basis of Arctic 211 (5). ${ }^{124}$ Article 234 raises, however, many questions such as its geographical application. ${ }^{125}$ It is unclear due to the wording, "within the limits of the exclusive economic zone," whether it applies only within the EEZ or if it also encompasses the territorial sea. ${ }^{126}$ The enhanced jurisdiction of the Coastal state applies within areas "[w]here particularly severe climatic conditions and the presence of ice covering such areas for most of the year." ${ }^{127}$ It is also required that the climate conditions and the ice cause damage or disturb the environment due to the wording, "[c]reate obstructions or exceptional hazards to navigation, and pollution of the marine environment could cause major harm to or irreversible disturbance of the ecological balance." $" 128$ The conditions are strict and cumulative and suggest that the provision is only applicable for a few areas. ${ }^{129}$

When the cumulative conditions are met, it follows from Article 234 that the coastal state is granted broad discretion to adopt regulations of shipping. ${ }^{130}$ The provision will therefore accommodate the lack of international regulations that are specific for the Arctic. The provision does not clarify what type

Convention: A Contribution to Safer Navigation in the Northwest Passage?, 42 OCEAN DEV. \& INT'L L. 22, 22-52 (2011) (discussing Article 234).

${ }^{123}$ LOS, supra note 7, art. 234.

${ }^{124}$ AMSA, supra note 2, at 66-67.

125 See Bartenstein, supra note 122, at 28-30 (discussing geographical application of article 234).

${ }^{126}$ LOS, supra note 7, art. 234.

${ }^{127} \mathrm{Id}$.

${ }^{128} \mathrm{Id}$.

129 The content of these conditions are discussed in Tore Henriksen, "Rollen til kyststaten i reguleringen av skipsfart i arktiske farvann", in Juss in Nord: Hav, fisk og urfolk, En hyllest til det juridiske fakultet ved Universitetet $i$ Tromsøs 25- årsjubileum, Tore Henriksen and Øyvind Ravna (eds.) Oslo 2012, p. $71-92$, p. $80-85$.

${ }^{130} I d$. at $86-88$. 
of regulations that may be adopted. It is however, reasonable to argue that the regulations as according to Article 211 (1) and (5) may relate to construction, design, equipment, manning requirements of the vessel as well as discharge standards and navigational standards. The coastal state may, for instance, adopt a ban on vessels that are carrying dangerous cargo, or a ban for vessels that do not comply with certain requirements that are necessary to navigate in the area. Article 234 does not clarify how strict regulations, which were adopted to protect icecovered areas from marine pollution, may be. It follows, however, from Article 34 that the Coastal state "shall have due regard to navigation and the protection and preservation of the marine environment." 131

It is clear that Article 234 with its wide competence for the coastal state facilitates environmental protection of ice-covered areas. This review of Article 234 shows, however, that it has a narrow scope of application and is therefore of limited significance in relation to implementing an integrated oceans management of the marine Arctic.

Also the IMO has recognized that certain areas need special protection, and provided some area-based management tools that are available to protect special areas also in the Arctic from shipping. These are PPSA (particularly sensitive sea areas) and MARPOL "special areas." 132 Within a MARPOL "special area," stricter standards with regard to the release of oil and other substances may be provided. ${ }^{133}$ "Special areas" are designated on the basis of the criteria developed by IMO on the basis of a proposal submitted by member states. ${ }^{134}$ There are no special areas so far in the Arctic. A challenge is that there are few ports

${ }^{131}$ LOS, supra note 7, art. 234.

132 Tanaka, supra note 116, at 325.

133 A "special area" may be established under MARPOL. MARPOL, supra note 109, annex I, II, V, VI. Guidelines for the establishment of "special area" under MARPOL are provided in I.M.O., G.A. Res. 927/22, U.N. Doc. A/RES/927/22 (Jan. 15, 2002).

134 See id. ( $\S 2.3-2.6$ discussing the criteria and process for the establishment of special areas). 
in the Arctic, which makes it difficult to meet the reception facilities that are required under MARPOL. ${ }^{135}$

Even though the MARPOL "special areas" is a relevant tool to prevent operation pollution in the sensitive environment in the Arctic, this tool is not further discussed in this article. Within MARPOL "special areas," only requirements with regard to discharges of substances may be adopted. Other impacts of shipping cannot be addressed. Thus, MARPOL "special areas" may contribute as one tool when implementing an integrated ocean management, but is not in itself a tool that facilitates this new approach to the oceans management.

In the next section, the focus is on the concept of PSSA. Through the use of PSSAs, all effects of shipping may be addressed, as all available IMO measures may be combined to protect a certain geographical area. In this way, this measure appears to be the available area- based management tool that best reflects the concept of an integrated ocean management. It will, therefore, be investigated to what extent PSSAs supports an integrated approach to the protection the marine environment.

\section{Particularly Sensitive Sea Areas (PSSAs)}

A PSSA is an area that needs special protection from shipping. The legal basis of PSSA is IMO Guidelines (hereinafter Guidelines), and it is, therefore, a soft law instrument with no legally binding basis. ${ }^{136}$ A PSSA is defined as "[a]n area that needs special protection through action by IMO because of its significance for recognized ecological, socioeconomic, or scientific attributes where such attributes may be vulnerable to damage by international shipping activities."137

A PSSA is adopted by IMO on the basis of a proposal from at least one member state. The criteria and the process for the adoption of a PSSA are set out in the Guidelines. ${ }^{138}$ The PSSA

${ }^{135}$ Aldo Chircop, supra note 111 , at 375-76.

${ }^{134}$ I.M.O., Res. A.982(24), U.N. Doc. A 24/Res.982, at 1 (Feb. 6, 2006) [hereinafter Revised Guidelines].

${ }^{137}$ Id. annex 91.2 .

${ }^{138} I d$. at $3,4,8$. 
Guidelines opens for the establishment of PSSAs within and beyond the limits of the territorial sea. ${ }^{139}$ In this way, the Guidelines provide that a sensitive area may be protected even though it covers different jurisdictional zones. This may contribute to overcome jurisdictional boundaries and may facilitate an integrated ocean management. If the member states agree on the establishment of a PSSA that cover areas of the high seas, this would not be a violation of international law or the freedom of the sea. ${ }^{140}$ The adoption of PSSA in the high seas requires, however, careful consideration with regard to what extent measures adopted within the PSSA may be mandatory for other states and also to what extent the measures may be enforced. ${ }^{141}$

Due to the PSSA criteria, the area must be vulnerable due to ecological, social, economic, cultural or scientific criteria. ${ }^{142}$ The ecological criteria states that the area must be unique, rare, critical, sensitive or representative and is thus compatible with criteria for selection of protected areas on the basis of the CBD and the OSPAR Convention. ${ }^{143}$ The concept of PSSA may, thus, assist states in addressing their environmental obligations to protect ecosystems and marine biodiversity.

In addition to the ecological criteria, the area must also be vulnerable to impacts of shipping. ${ }^{144}$ An overly strict interpretation and application of this condition can make it difficult to comply with this, at least in some parts of the marine Arctic, with the relative few ships that are navigating. Here, a

${ }^{139} I d$. annex $\uparrow 4.3$, at 5 .

${ }^{140}$ Henrik Ringbom argues that the establishment of PSSAs on the high seas may be justified on the basis of legal instrument that provide for protection measures on the high seas, see HENRIK RINGBOM, THE EU MARITIME SAFETY POLICY AND INTERNATIONAL LAW(2008) p.463-464. The OSPAR Commission has for instance also adopted several MPAs on the high seas. These Decisions are available at http://www.ospar.org/v_measures/ browse.asp?menu $=00510416000000 \_000000 \_00000$

${ }^{141}$ See Markus J. Kachel, Particularly Sensitive Sea Areas: The IMO's Role in Protecting Vulnerable Marine Areas 274-83 (2008) (discussing PSSA on the high seas).

${ }^{142}$ Revised Guidelines, supra note 134, at 4.

${ }^{143}$ Id. at 4.4.1-4.4.11. See also supra note 137, at 237- 241.

${ }^{144} \mathrm{Id}$. at 7, 1 甲 5.1.1- 5.1.4. 
precautionary approach should be applied by IMO when evaluating the conditions, as the consequences of an accident with oil spills may be much more severe in the sensitive Arctic environment than in other areas. In the same direction, it is argued by Chircop that, "[a] low volume of shipping that qualitatively has the potential of greater impact could provide sufficient justification for PSSA designation, as long as the threat is demonstrated." $" 145$

At the time of the adoption of a PSSA, at least one associated protective measure must be adopted. ${ }^{146}$ The Guidelines dictate which measures are possible. First, the area may be designated as a special area under MARPOL Annex I, II, $\mathrm{V}$, or as an SOx emission control area under MARPOL VI. ${ }^{147}$ Second, routing measures or reporting systems under the SOLAS Convention may be adopted. ${ }^{148}$ The traffic may, for instance, be led outside the most critical part of the area, through the use of sea-lanes. Finally, also other new measures may according to the Guidelines be developed and adopted to protect the specific sensitive sea are, provided that it has an identified legal basis. ${ }^{149}$ The Guidelines are clarifying what the "identified legal basis" may be ${ }^{150}$ This is described as any measure available under IMO instrument and any measures that could become available through amendment or adoption of a new IMO instrument. ${ }^{151}$ The Guidelines also provides that any measure that may be proposed in the territorial sea or on the basis of article 211 (6) in the LOSC may be adopted within the PSSA. ${ }^{152}$

It should be noted that it is not a requirement that the measure is legally binding. ${ }^{153}$ This means that the Arctic states could propose as a protective measure a regulation that follows

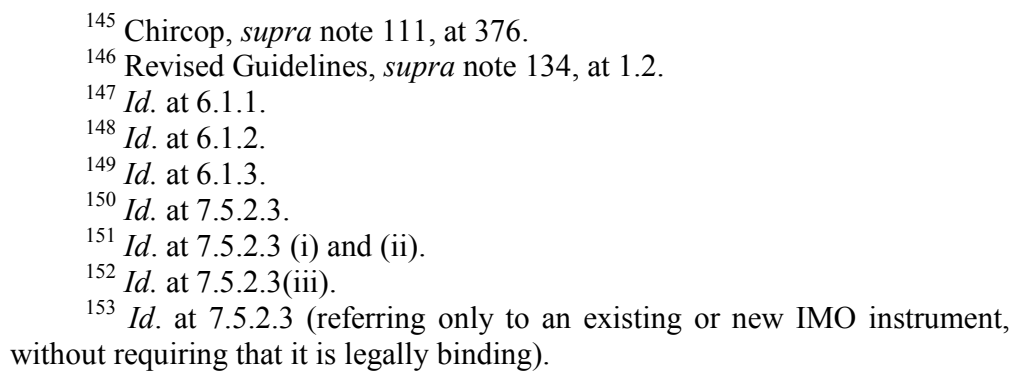

${ }^{153} \mathrm{Id}$. at 7.5.2.3 (referring only to an existing or new IMO instrument, without requiring that it is legally binding). 
from the Polar Guidelines adopted by IMO. So far, the protective measures adopted to protect the PSSAs have not been controversial. ${ }^{154}$ The Guidelines provide, however, for a possibility and a certain scope for developing new regulations that would be tailored to protect the particular sensitive sea area against shipping. ${ }^{155}$ The adoption of a PSSA may therefore give the states in cooperation with IMO a possibility to go beyond the "normal" jurisdiction to regulate shipping. ${ }^{156}$

\section{CONCLUSION}

Important steps to implement the legal requirements of an integrated oceans management are taken by the Arctic Council. In the face of the development with melting of ice and increasing shipping activities, it is crucial that an integrated oceans management in the marine Arctic also covers the impacts of shipping. Although PSSA is not a legally binding tool, it is in this regard not entirely void of legal significance.

First, when an area is recognized as a PSSA, the area will be internationally recognized as sensitive, which is of symbolic significance. Furthermore, as a PSSA may cover maritime zones beyond the territorial sea, the PSSAs may, therefore, bridge jurisdictional gaps. If the PSSA extends from the Coastal states maritime zones to the high seas, the whole ecosystem may be protected regardless of the jurisdictional limits of the law of the sea. Through the process of designating a PSSA the ecological values of the area is assessed and all impacts of shipping may be addressed. This provides for a thorough, holistic approach to the area, where the states in cooperation with IMO may evaluate the areas significance for species and marine ecosystems and then adopt measures that are tailored to protect these ecological values. As the Guidelines open for the development of new

154 Henrik Ringbom, Regulatory Layers in Shipping, in THE WORLD Ocean in Globalisation: Climate Change, Sustainable Fisheries, Biodiversity, Shipping, Regional Issues 353 (Davor Vidas \& Peter J. Schei eds., 2011).

\footnotetext{
${ }^{155}$ Id. at 354 .

${ }^{56} \mathrm{Id}$.
} 
measures within IMO, a PSSA status provides flexibility and the possibility to respond to new emerging environmental threats.

Conclusively, the best way forward when implementing environmental requirements of holistic and integrated approaches, is that the Arctic states cooperate with each other and make proposals for either a large PSSAs in the Arctic Ocean, or smaller PSSAs to protect critical areas, to ensure protection of their fragile sea areas. As for the high seas, it will be interesting to see what the states may accomplish under the Arctic Council. 